\title{
Study of adsorption isotherms and physicochemical characterization of natural food colourants
}

\author{
Kéllen Wanessa Coutinho VIANA ${ }^{1 *}$, Isadora Rebouças Nolasco de OLIVEIRA², Juliana de Cássia Gomes ROCHA ${ }^{1}$, \\ Frederico Augusto Ribeiro de BARROS ${ }^{1}$, Paulo César STRINGHETA ${ }^{1}$
}

\begin{abstract}
Synthetic colourants are widely used for colouring foods. However, their safety has been questioned. Due to this limitation and the global trend of consuming healthy foods, the industry is faced with the need to replace artificial colourings, which has given rise to a growing interest in colourants from natural sources. Thus, this work obtained the moisture adsorption isotherms of the natural food dyes of anthocyanins, betalains and curcumin and evaluated the humidity, water activity $\left(a_{w}\right)$, hygroscopicity, colour and antioxidant capacity in vitro. Isotherms were determined by the static gravimetric method with saturated salt solutions ( $\mathrm{LiCl} . \mathrm{H}_{2} \mathrm{O}, \mathrm{MgCl}_{2} \cdot 6 \mathrm{H}_{2} \mathrm{O}, \mathrm{Mg}\left(\mathrm{NO}_{3}\right)_{2} \cdot 6 \mathrm{H}_{2} \mathrm{O}, \mathrm{NaCl}, \mathrm{KCl}$ and $\mathrm{K}_{2} \mathrm{SO}_{4}$ ) at $25^{\circ} \mathrm{C}$. Experimental data were adjusted by $\mathrm{GAB}$, BET, Halsey, Oswin and Henderson models. All models, except Henderson's for Curcumin, fitted the data and BET was used to represent the moisture adsorption isotherm. All the isotherms were type sigmoidal, characteristic of most foods. The observed water content $(<0.3 \%)$ and $a_{\mathrm{w}}(<0.03)$ can be considered favourable to stability. Colour analysis indicated a high colouring strength and the antioxidant capacity suggested that, in addition to representing a source of colour in food products, natural dyes may have an additional function, with possible health benefits.
\end{abstract}

Keywords: natural dyes; anthocyanins; betalains; curcumin; adsorption isotherm.

Practical Application: Natural colorants can be used successfully to color food products and may exert an additional function with health benefits.

\section{Introduction}

Colour is one of the main sensory attributes that influence the choice and acceptance of food by consumers and is also considered an important parameter in quality control. During processing, the addition of either or both natural and synthetic dyes aims to restore the original colour lost or to give colour to colourless foods (Aberoumand, 2011).

Synthetic dyes are widely used by the food industry, as they enable intense colours and are stable. However, some studies evidence adverse reactions associated with the consumption of these food additives, such as the development of some types of cancer, allergic reactions, induction of hyperactivity and behavioural changes in children (McCann et al., 2007; Stevens et al., 2011; Kus \& Eroglu, 2015). Consequently, their safety has been questioned with increasing intensity, leading to the prohibition of the use of some of these dyes in food.

Consumer concerns regarding the safety of consuming synthetic dyes have forced the food industry to find natural sources as replacements. The use of natural dyes is a current market trend, not only for its colour function but also for the potential health benefits attributed to natural pigments, which include antioxidant properties and prevention of cardiovascular diseases and neurological conditions (Pascual-Teresa, 2014; Esatbeyoglu et al., 2015; Rodriguez-Amaya, 2016).
Curcumin, anthocyanins and betalains are among the most used natural dyes for commercial application in foods. Anthocyanins are water-soluble pigments, widely distributed in the plant kingdom. The hue of anthocyanins varies as a function of $\mathrm{pH}$, and their stability is dependent on factors, such as temperature, and the presence of light and oxygen. Betalains are red, yellow, pink or orange pigments, derived primarily from beetroot. Curcumin is a yellow pigment obtained from the roots of turmeric. It shows limited water-solubility and its stability depends mainly on exposure to light and $\mathrm{pH}$ changes (Akram et al., 2010; Buchweitz et al., 2013; Güneşer, 2016; Mondal et al., 2016; Celli \& Brooks, 2017).

The interest in the possible beneficial effects of natural pigments for human health has motivated the evaluation of their various aspects, such as structure, stability and antioxidant capacity (Khalil et al., 2012; Piyarat et al., 2014; Sui et al., 2014; $\mathrm{Xu}$ et al., 2015). However, moisture adsorption isotherms data on natural dyes commercially available for use in foods is scarce.

In the present work, it was obtained for the first time, to the best of our knowledge, the moisture adsorption isotherms from natural food dyes that are available for commercial use (anthocyanins, betalains and curcumin). The moisture, water activity $\left(a_{\mathrm{w}}\right)$, hygroscopicity, colour and antioxidant capacity of the natural dyes were also determined.

${ }^{1}$ Laboratório de Corantes Naturais e Compostos Bioativos, Departamento de Tecnologia de Alimentos, Universidade Federal de Viçosa - UFV, Viçosa, MG, Brasil ${ }^{2}$ Departamento de Ciência e Tecnologia de Alimentos, Instituto de Ciências Agrárias, Universidade Federal de Viçosa - UFV, Rio Paranaíba, MG, Brasil

${ }^{*}$ Corresponding author: kellenviana@live.com 


\section{Materials and methods}

The natural dyes investigated included anthocyanins from grapes, curcumin from turmeric roots and betalains from beetroot, all kindly provided by Christian Hansen Industria e Comércio Ltd (Valinhos, São Paulo, Brazil), in the form of soluble powders and without additional purification. Potassium sorbate and reagent grade citric acid and disodium phosphate anhydrous were purchased from Sigma-Aldrich Company (St Louis, MO, USA).

The humidity was determined gravimetrically, vacuum oven drying at $70{ }^{\circ} \mathrm{C}$ until constant weight, according to the Association of Official Analytical Chemists (2006). The $a_{\mathrm{w}}$ was measured automatically with a Testo 650 apparatus (Hannover, Germany), at $25.2 \pm 0.03{ }^{\circ} \mathrm{C}$. Hygroscopicity was determined by the static gravimetric method with saturated $\mathrm{NaCl}$ solution (75\% relative humidity $(\mathrm{RH}), a_{\mathrm{w}}=0.75$ ) (Taylor, 1961), and was defined as the equilibrium moisture reached by the dyes when exposed to $75 \% \mathrm{RH}$. All determinations were performed in quadruplicates.

The moisture adsorption isotherms were determined in triplicate, by the static gravimetric method, at room temperature $\left(25^{\circ} \mathrm{C}\right)$, as described by Labuza $\& \mathrm{Schmidl}$ (1985). Six saturated salt solutions $\left(\mathrm{LiCl} . \mathrm{H}_{2} \mathrm{O}, \mathrm{MgCl}_{2} \cdot 6 \mathrm{H}_{2} \mathrm{O}, \mathrm{Mg}\left(\mathrm{NO}_{3}\right)_{2} \cdot 6 \mathrm{H}_{2} \mathrm{O}, \mathrm{NaCl}\right.$, $\mathrm{KCl}$ and $\mathrm{K}_{2} \mathrm{SO}_{4}$ ), were used to obtain environments with a $\mathrm{RH}$ equivalent to $11,32.8,52.9,75.3,84.3$ and $97.3 \%$, respectively, corresponding to $0.110,0.328,0.529,0.753,0.843,0.973 a_{\mathrm{w}}$ (Rossi \& Roa, 1980).

The samples were initially submitted to drying at $70{ }^{\circ} \mathrm{C}$ in a vacuum oven (TE 395-1, Tecnal) and for heat removal, placed in desiccator containing silica gel and cooled to room temperature. After weighing, the dried samples were conditioned in hermetically sealed glass desiccators containing the saline solutions, simulating different levels of relative humidity, at room temperature controlled by air conditioning.

The evaluation of the moisture gain by weighing the capsules in an analytical balance (Mark 210A, Bel engineering, Monza, Italy) was carried out daily until the samples reached a hygroscopic equilibrium, that is, until a constant mass. The equilibrium moisture contents were determined based on the mass difference of the samples.

For the mathematical modelling of the isotherms, theoretical and empirical models of Guggenheim-Anderson-de Boer (GAB), Brunauer-Emmett-Teller (BET), Oswin, Halsey and Henderson (Table 1) fitted the experimental data. The models were adjusted using an optimisation based on the Gauss-Newton method and convergence criteria of $10^{-6}$, resolved by mathematical processor Statistica $7^{\circledR}$ (Statsoft Inc., 2004).

The coefficient of determination $\left(R^{2}\right)$ (Equation 1$)$, the error $(\varepsilon)$ between the experimental and predicted moisture values (Equation 2) and the mean of errors $\left(\left|\varepsilon_{\mathrm{m}}\right|\right)$ (Equation 3) were used to evaluate the fit of the models to the experimental data. Mean values of errors less than $10 \%$ were considered as indicators of fine adjustments for the sorption isotherms (Peng et al., 2007).

$$
R^{2}=1-\frac{\text { SQresiduo }}{\text { SQtotal }}
$$

$$
\begin{aligned}
& \mathcal{E}{ }_{i=\frac{M_{\text {eppi }}}{}-M_{\text {teo }}} \\
& \left|\varepsilon_{m}\right|=\frac{\sum_{i=1}^{N} \varepsilon_{i}}{N}
\end{aligned}
$$

where $S Q=$ sum of the square; $M_{\text {exp } i}=$ equilibrium moisture obtained experimentally; $M_{\text {teori }}=$ equilibrium moisture predicted by the model; $\varepsilon_{i}=$ relative error, and $N=$ number of samples.

The colour characterisation was performed in quadruplicate for each natural dye $(0.2 \mathrm{~g})$ solubilised in a buffer solution $(20 \mathrm{~mL})$. For anthocyanins, the solution $\mathrm{pH}$ was 3 , whereas, for betalains and curcumin the solution $\mathrm{pH}$ was 4 , given that anthocyanin pigments are more stable at the lower $\mathrm{pH}$ (Pedro et al., 2016) and the others at the higher $\mathrm{pH}$ (Herbach et al., 2006; Suresh et al., 2007). The colour of the solutions was determined using CIELab parameters, with the aid of a ColorQuest instrument (HunterLab., Reston, Virginia, USA). The readings of the chromaticity coordinates $L^{*}$ (brightness; $0=$ black, $100=$ white), $a^{\star}($ positive $=$ red, negative $=$ green $)$ and $b^{\star}($ positive $=$ yellow, negative $=$ blue $)$ were used to calculate the hue angle $\left(h^{\star}\right)$ (Equation 4) and saturation index $\left(C^{\star}\right)$ (Equation 5).

$$
h^{*}=\arctan \left(\frac{b^{*}}{a^{*}}\right)
$$

$C^{*}=\sqrt{a^{* 2}+b^{* 2}}$

The antioxidant capacity of the natural dyes was determined by the Trolox equivalent antioxidant capacity (TEAC) assay, performed in triplicate, with the cationic 2,2'-azinobis(3-ethylbenzothiazoline-6-sulphonic acid) radical (ABTS $\bullet$ ), adapted from Re et al. (1999).

Table 1. Models used to fit the moisture adsorption isotherms of natural dyes.

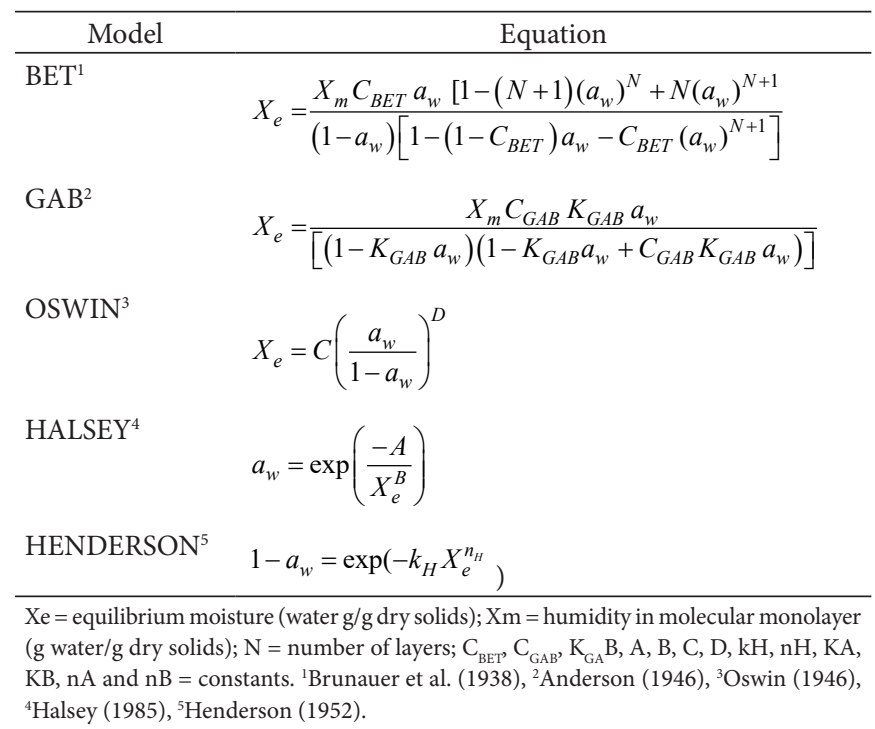




\section{Results and discussion}

The moisture, $a_{\mathrm{w}}$ and hygroscopicity values (Table 2), confirmed the ease by which the pigments are extracted and effectively dried by the manufacturing industry.

The low moisture values $(<3 \%)$, indicated that the water content of the dyes is low, which contributes to their stability and hygroscopic behaviour. Tonon et al. (2009) found 2.57-2.88\% moisture for spray-dried açaí, with maltodextrin as the carrier, whereas Silva et al. (2013) evaluated various carrier agents and temperatures during the spray drying of jabuticaba extracts, and observed a final humidity of the powders between 2.11 and $6.73 \%$. For beet juice powders prepared by several different drying methods, between 2.3 and $8.4 \%$ humidity was recorded (Nemzer et al., 2011; Pitalua et al., 2010). The literature data verify that the moisture content of a powder depends on the matrix used and the drying conditions to which it was subjected.

The $a_{\mathrm{w}}$ of the dyes can be regarded as favourable to stability, considering that under these conditions, there is no microbial growth and reactions, such as non-enzymatic browning, occur relatively slowly (Reid \& Fennema, 2010). Compared to the values obtained in the current study, Duangmal et al. (2008) obtained lower $a_{\mathrm{w}}(0.11$ to 0.14$)$ for anthocyanin roselle extracts, produced with maltodextrin as the carrier. The authors observed that there was greater stability for anthocyanins at a lower $a_{\mathrm{w}}$. For açaí powder, the $a_{\mathrm{w}}$ ranged from 0.19-0.24, depending on the drying aid used, which, according to its chemical structure, causes differences in this parameter (Tonon et al., 2009).
Hygroscopicity, often determined in powdered products, is one of the most important properties in determining shelf life and stability during storage of food powders. The higher the hygroscopic value, the greater the susceptibility of the food to deterioration (Reid \& Fennema, 2010). Caparino et al. (2012) observed hygroscopicity between 16.5 and $20.1 \mathrm{~g} \cdot 100 \mathrm{~g} \mathrm{~g}^{-1}$ in mango powder produced by numerous drying methods. In jaboticaba extract powders, hygroscopicity ranged from $13.29-17.96 \mathrm{~g} \cdot 100 \mathrm{~g}^{-1}$ and was dependent on the spray drying temperature and carrier agent (Silva et al., 2013). Hence, the type and concentration of carrier agent, temperature and drying method influence the hygroscopicity of powdered products, which may explain the data variation among the dye samples, which were processed with different carrier agents (glucose syrup for the anthocyanin dye, and maltodextrin for the betalain and curcumin dyes). Moreover, the results demonstrate the stability of these natural dyes under proper storage conditions and their high tolerance to microbial deterioration and degradation reactions. Such findings may imply a broader and safer use of these compounds, given that one limitation in the use of natural dyes is their susceptibility to microbial contamination, as they are materials of animal or vegetable origin.

The $R^{2}$ and $\left|\varepsilon_{\mathrm{m}}\right|$ of the estimated parameters of the adsorption isotherm models are shown in Table 3. All models, except Henderson for curcumin, fitted appropriately to the experimental data, with $R^{2}$ values close to 1 . The $\left|\varepsilon_{\mathrm{m}}\right|$ values for the BET and Halsey models were lower than $10 \%$ for all the natural dyes. Mean deviations above this value were obtained with the Oswin

Table 2. Moisture, water activity and hygroscopicity of natural dyes.

\begin{tabular}{cccc}
\hline Dye & Moisture (\%) & Water Activity & Hygroscopicity $\left(\mathrm{g} \cdot 100 \mathrm{~g}^{-1}\right)$ \\
\hline Anthocyanin & $1.68 \pm 0.134$ & $0.41 \pm 0.003$ & $27.49 \pm 0.82$ \\
Betalaína & $2.63 \pm 0.125$ & $0.54 \pm 0.004$ & $22.65 \pm 0.46$ \\
Curcumin & $1.96 \pm 0.117$ & $0.39 \pm 0.068$ & $12.07 \pm 0.36$ \\
\hline
\end{tabular}

Values represent the mean $(n=4) \pm$ standard deviation.

Table 3. Estimated parameters of adsorption isotherms for natural dyes.

\begin{tabular}{|c|c|c|c|c|}
\hline \multirow{2}{*}{ Model } & \multirow{2}{*}{ Parameters and constants } & \multicolumn{3}{|c|}{ Natural dyes } \\
\hline & & Anthocyanin & Betalain & Curcumin \\
\hline \multirow[t]{5}{*}{ BET } & $X_{m}$ & 3.10 & 2.61 & 23.24 \\
\hline & $C_{B E T}$ & 21.60 & 20.33 & 0.22 \\
\hline & $N$ & 34.14 & 29.43 & 10.16 \\
\hline & $R^{2}$ & 0.9904 & 0.9967 & 0.9961 \\
\hline & $\left|\varepsilon_{m}\right|$ & 5.49 & 3.64 & 5.85 \\
\hline \multirow[t]{4}{*}{ OSWIN } & C & 7.55 & 6.36 & 3.40 \\
\hline & $D$ & 0.57 & 0.47 & 0.50 \\
\hline & $R^{2}$ & 0.9947 & 0.9978 & 0.9948 \\
\hline & $\left|\varepsilon_{m}\right|$ & 17.39 & 9.96 & 13.47 \\
\hline \multirow[t]{4}{*}{ Halsey } & $A$ & 1.82 & 2.15 & 2.93 \\
\hline & $B$ & 0.98 & 0.81 & 0.86 \\
\hline & $R^{2}$ & 0.9655 & 0.9593 & 0.9661 \\
\hline & $\left|\varepsilon_{m}\right|$ & 1.52 & 0.86 & 3.61 \\
\hline \multirow[t]{4}{*}{ Henderson } & $k_{H}$ & 0.12 & 0.16 & 0.14 \\
\hline & $n_{H}$ & 0.90 & 0.85 & 3.53 \\
\hline & $R^{2}$ & 0.9779 & 0.9727 & 0.6552 \\
\hline & $\left|\varepsilon_{m}\right|$ & 4.92 & 4.23 & 23.87 \\
\hline
\end{tabular}


model for all the samples and with the Henderson model only for curcumin.

The BET model is one of the most used in the literature because it is related to the water sorption process. Based on the $R^{2}$ and $\left|\varepsilon_{\mathrm{m}}\right|$ values (Table 3 ) and the theoretical basis of the BET model, it was selected to represent the adsorption isotherms of the natural dyes. The BET monolayer moisture $\left(X_{m}\right)$ is an important parameter as it indicates the amount of water strongly adsorbed to specific sites on the surface of the material. It provides a first estimate of the moisture content at which a dehydrated product illustrates maximum stability (Reid \& Fennema, 2010).

The $X_{m}$ values (Table 3) correspond to the moisture content considered safe to ensure the dyes stability during storage. For the anthocyanin and betalain dyes, these values agreed with the literature data for Bordo grape (3.53-4.17\%), açaí (3.1-5.8\%), raspberries (5.9\%) and beetroot (3.27-6.04\%) powder, but proved to be lower than tomato pulp (18.96\%), and blueberry (18.9\%) powders (Chranioti et al., 2015; Souza et al., 2015; Goula et al., 2008; Jiménez-Aguilar et al., 2011; Syamaladevi et al., 2009; Tonon et al., 2009). However, the $X_{m}$ for curcumin was shown to be superior to those cited above, suggesting that during storage, this dye is more stable compared to the powdered anthocyanins and betalains. Therefore, among the dyes evaluated, curcumin was the most stable, as it showed the lowest $a_{\mathrm{w}}$ and hygroscopicity values and, also, the highest $X_{m}$.

The BET model fitted the experimental data (Figure 1). All samples showed a sigmoidal sorption isotherm, characteristic of most foods (Reid \& Fennema, 2010). Although the samples

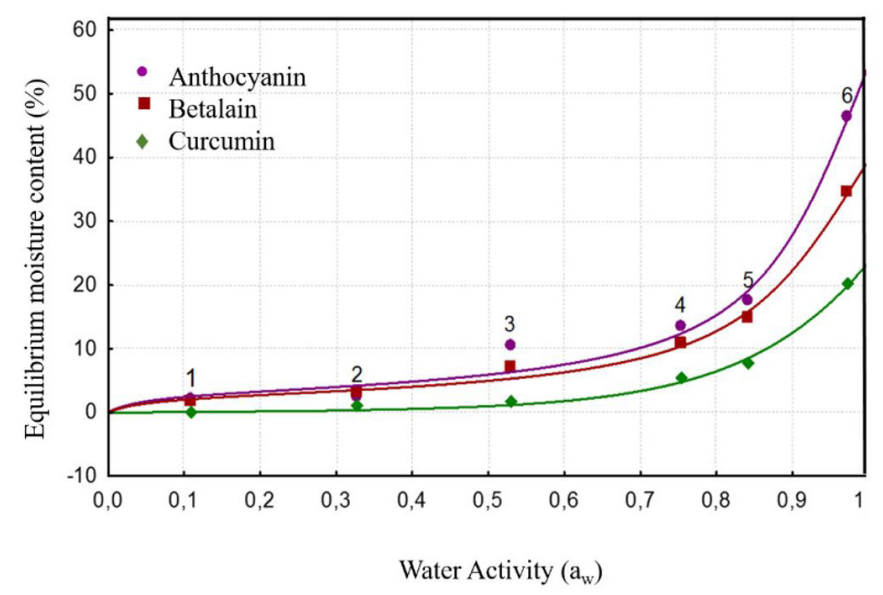

Figure 1. Adsorption isotherms of natural dyes. had similar characteristics, the curves of the natural dyes differed among themselves. According to Mathlouthi \& Rogé (2003) and Szulc \& Lenart (2012), powdered products have a complex structure, including soluble substances able to crystallise during the adsorption of water and, depending on the nature (amorphous or crystalline), the shape of the isotherm is different.

At low $a_{\mathrm{w}}$ values, the samples showed a less hygroscopic behaviour, while at higher $a_{\mathrm{w}}$ there was a greater adsorption (Figure 1). Such a trend indicates that the higher the RH of the environment, the more hygroscopic and, consequently, the more susceptible the dye to undesirable reactions, and the greater care required for handling and storage. This same tendency was observed by Tonon et al. (2009) in açai juice powder, by Jiménez-Aguilar et al. (2011) in blueberry anthocyanin extract powders and by (Mosquera et al., 2012) in strawberry powder. Among the samples, the natural curcumin dye was shown to be the less hygroscopic, followed by betalain and anthocyanin, respectively (Tables 3 and 4 ). This difference is expected, given the dyes are produced from different sources and carriers and have distinct compositions. Tonon et al. (2009) documented that the particle size produced by the carrier agent may be associated with differences in water adsorption. The smaller the particle size, the greater the exposed surface and, consequently, the greater the adsorption of water from the environment.

The adsorption isotherms constructed, illustrate the hygroscopic behaviour of commercially available natural dyes for use in food, providing valuable insight into these compounds. The graphs (Figure 1) establish that when stored in low RH environments, anthocyanin and betalain dyes are more stable than curcumin dye.

The colour of natural dyes is affected by the concentration of the colouring principle, extraction methods, concentration and type of carrier agent, $\mathrm{pH}$, and storage conditions (Cavalcanti et al., 2011; Herbach et al., 2006; Lin et al., 2009). The chromaticity coordinates $L^{*}, a^{*}, b^{*}, C^{\star}$ and $h^{*}$ of the three natural dyes evaluated, are shown in Table 4 . The $L^{*}$ values can be considered low, while the positive $a^{*}$ and $b^{*}$ values indicate the presence of red, particularly regarding the anthocyanin and betalain dyes and yellow, predominantly in the curcumin dye. These values were confirmed by the $h^{*}$ data, which ranged from 0 to $25^{\circ}$ for the anthocyanin and betalain dyes, indicating red tonality, and between 70 and $100^{\circ}$ for curcumin, corresponding to a yellow tone. Moreover, these results concurred with those found in the literature for dyes and extracts produced with anthocyanins, betalains and curcumin, from various sources (Rosso \& Mercadante, 2007; Herrera-Hernández et al., 2011;

Table 4. Chromaticity coordinates of natural dyes.

\begin{tabular}{lrrr}
\hline \multirow{2}{*}{ Parameters } & \multicolumn{3}{c}{ Natural dyes } \\
\cline { 2 - 4 } & Anthocyanin & Betalain & Curcumin \\
\hline$L^{*}$ - Brightness & $27.8 \pm 0.029$ & $32.77 \pm 0.032$ & $45.54 \pm 0.163$ \\
$a^{*}$ - Red (+ a) and Green (- a) & $8.45 \pm 0.026$ & $31.34 \pm 0.064$ & $8.33 \pm 0.067$ \\
$b^{*}$ - Yellow (+ b) and Blue (- b) & $1.48 \pm 0.038$ & $10.96 \pm 0.035$ & $33.42 \pm 0.234$ \\
$C^{*}$ - Color Saturation (Chroma) & $8.58 \pm 0.030$ & $33.20 \pm 0.066$ & $34.44 \pm 0.211$ \\
$H^{*}$ - Hue Angle (Degrees) & $9.93 \pm 1.370$ & $19.27 \pm 0.049$ & $76.00 \pm 0.202$ \\
\hline
\end{tabular}

Values represent the mean $(n=4) \pm$ standard deviation. 
Jiménez-Aguilar et al., 2011; Lim et al., 2011; Pitalua et al., 2010). A higher $C^{\star}$ value is related to a higher purity or colour intensity of the sample evaluated. The anthocyanin dye had a $C^{\star}$ of 8.58 , which indicates a less saturated, less pure colour. The $C^{\star}$ values for the remaining two dyes were relatively high, which means that the colour provided was pure and intense.

Besides their colouring function, natural dyes are comprised of certain compounds that display antioxidant properties. Anthocyanins have been linked to the prevention of some diseases, and their antioxidant action is well-established (Kruger et al., 2014; Yang \& Zhai, 2010). The antioxidant capacity of the anthocyanin dye $\left(1166.59 \pm 18.97 \mu \mathrm{M} \cdot \mathrm{L}^{-1}\right.$ Trolox $\left.\cdot \mathrm{g}^{-1}\right)$ was much higher than that found by Souza et al. (2014), for Bordo grape extracts produced with various concentrations of maltodextrin as the carrier. In that study, the 2,2-diphenyl-1-picrylhydrazyl (DPPH•) antioxidant activity ranged from $25.4 \pm 0.8-74.9 \pm 0.3 \mu \mathrm{mol} \cdot \mathrm{L}^{-1}$ Trolox $\mathrm{g}^{-1}$, and $66.2 \pm 0.3-231.5 \pm 0.9 \mu \mathrm{mol} \cdot \mathrm{L}^{-1}$ Trolox $\mathrm{g}^{-1}$, based on the ferric reducing antioxidant power (FRAP) assay. According to the same authors, the antioxidant capacity of the samples decreased with increasing carrier content, due to the dilution effect of the extract. Conversely, the antioxidant capability of the evaluated anthocyanin dye was similar to that reported by Tonon et al. (2010) for açaí powder, using the DPPH method, which varied from $1101.73 \pm 36.11-1165.84 \pm 35.29 \mu \mathrm{mol} \cdot \mathrm{L}^{-1}$ Trolox $\cdot \mathrm{g}^{-1}$, depending on the carrier agent used.

The pulp, juice and dye of beets are recommended as sources of bioactive compounds and as functional ingredients, due to the betalains contained in these vegetables, which possess antioxidant capacity (Vulić et al., 2012; Wootton-Beard \& Ryan, 2011; Azeredo, 2009). The TEAC of the betalain dye $\left(22.57 \pm 0.26 \mu \mathrm{mol} \cdot \mathrm{L}^{-1}\right.$ Trolox $\left.\cdot \mathrm{g}^{-1}\right)$ was higher than that mentioned in the literature for betalains extracted from the same source. Figiel (2010) analysed beets dehydrated by three different methods and determined between 0.49 and $0.66 \mu \mathrm{mol} \cdot \mathrm{L}^{-1}$ Trolox $\cdot \mathrm{g}^{-1}$, by the FRAP assay. Gonçalves et al. (2013) measured the TEAC of purified betanin as $4.9 \pm 0.7 \mu \mathrm{mol} \cdot \mathrm{L}^{-1}$ Trolox $\cdot \mathrm{g}^{-1}$. Commercial dyes typically have a more complex composition than non-commercial dyes, which hinders the interpretation of the data and may explain the great differences between the antioxidant capacity of the analysed dye and those in the literature. For example, betalain dye also contains another antioxidant in its composition (citric acid), added to increase pigment stability (Gonçalves et al., 2013; Herbach et al., 2006).

The TEAC of the curcumin dye $\left(167.32 \pm 9.39 \mu \mathrm{mol} \cdot \mathrm{L}^{-1}\right.$ Trolox $\left.\cdot \mathrm{g}^{-1}\right)$, confirms its potential as an antiradical. Several studies have emphasised the potent antioxidant power of the curcuminoids present in this dye (Chranioti et al., 2015; Kutti Gounder \& Lingamallu, 2012; Lim et al., 2011; Singh et al., 2010). According to Jayaprakasha et al. (2006), besides being the major colour component, compared to demethoxycurcumin and bisdemethoxycurcumin curcuminoids, curcumin has higher in vitro antioxidant activity, reaching $3099 \pm 66 \mu \mathrm{mol} \cdot \mathrm{L}^{-1}$ ascorbic acid $\mathrm{g}^{-1}$. Other studies illustrated that the efficacy of curcumin to prevent auto-oxidation of linoleic acid was due to its inhibitory action on hydrogen peroxide and superoxide radicals (via electron donation and free radical neutralisation), as well as its chelation of ferrous ions $\left(\mathrm{Fe}^{2+}\right)$, in several in vitro antioxidant assays (Martins et al., 2013; Singh et al., 2010; Ak \& Gülçin, 2008).
The antioxidant capacity of the natural dyes seems to be affected by factors, such as pigment source, $\mathrm{pH}$, anthocyanin, betalain or curcuminoid contents, the concentration of the carrier agents used in drying, the evaluation method and sample presentation (fruit, powder). This behaviour may explain the differences found between the experimental values and those reported in the literature.

\section{Conclusions}

The water content, $a_{\mathrm{w}}$ and hygroscopicity of the natural dyes evaluated indicate their storage stability from a physical, enzymatic and microbiological perspective. The isotherms obtained for the three dyes showed a sigmoidal shape, characteristic of most powdered food products, and the BET model was considered the most representative. The dyes displayed intense colours and a high colouring power, indicating that these compounds can be used successfully to colour food products. Moreover, the high antioxidant capacities demonstrated that when used as a colour source in foods, natural dyes may exert an additional function with health benefits.

\section{References}

Aberoumand, A. (2011). A review article on edible pigments properties and sources as natural biocolorants in foodstuff and food industry. World Journal of Dairy \& Food Sciences, 6(1), 71-78.

Ak, T., \& Gülçin, I. (2008). Antioxidant and radical scavenging properties of curcumin. Chemico-Biological Interactions, 174(1), 27-37. http:// dx.doi.org/10.1016/j.cbi.2008.05.003. PMid:18547552.

Akram, M., Ahmed, A., Usmanghani, K., Hannan, A., Mohiuddin, E., \& Asif, M. (2010). Curcuma longa and curcumin: a review article. Romanian Journal of Biology Plant Biology, 55(2), 65-70.

Anderson, R. B. (1946). Modifications of the Brunauer, Emmett and Teller equation. Journal of the American Chemical Society, 68(4), 686-691. http://dx.doi.org/10.1021/ja01208a049. PMid:18861755.

Association of Official Analytical Chemists - AOAC. (2006). Official Methods of Analysis (18th ed.). Gaithersburg: Association of Official Analytical Chemists.

Azeredo, H. M. C. (2009). Betalains: properties, sources, applications, and stability - a review. International Journal of Food Science \& Technology, 44(12), 2365-2376. http://dx.doi.org/10.1111/j.13652621.2007.01668.x.

Brunauer, S., Emmett, P. H., \& Teller, E. (1938). Adsorption of gases in multimolecular layers. Journal of the American Chemical Society, 60(2), 309-319. http://dx.doi.org/10.1021/ja01269a023.

Buchweitz, M., Brauch, J., Carle, R., \& Kammerer, D. R. (2013). Colour and stability assessment of blue ferric anthocyanin chelates in liquid pectin-stabilised model systems. Food Chemistry, 138(2-3), 2026-2035. http://dx.doi.org/10.1016/j.foodchem.2012.10.090. PMid:23411339.

Caparino, O. A., Tang, J., Nindo, C. I., Sablani, S. S., Powers, J. R., \& Fellman, J. K. (2012). Effect of drying methods on the physical properties and microstructures of mango (Philippine "Carabao" var.) powder. Journal of Food Engineering, 111(1), 135-148. http:// dx.doi.org/10.1016/j.jfoodeng.2012.01.010.

Cavalcanti, R. N., Santos, D. T., \& Meireles, M. A. A. (2011). Nonthermal stabilization mechanisms of anthocyanins in model and food systems-an overview. Food Research International, 44(2), 499-509. http://dx.doi.org/10.1016/j.foodres.2010.12.007. 
Celli, G. B., \& Brooks, M. S.-L. (2017). Impact of extraction and processing conditions on betalains and comparison of properties with anthocyanins - a current review. Food Research International, 100(Pt 3), 501-509. http://dx.doi.org/10.1016/j.foodres.2016.08.034. PMid:28964374.

Chranioti, C., Nikoloudaki, A., \& Tzia, C. (2015). Saffron and beetroot extracts encapsulated in maltodextrin, gum Arabic, modified starch and chitosan: incorporation in a chewing gum system. Carbohydrate Polymers, 127, 252-263. http://dx.doi.org/10.1016/j. carbpol.2015.03.049. PMid:25965482.

Duangmal, K., Saicheua, B., \& Sueeprasan, S. (2008). Colour evaluation of freeze-dried roselle extract as a natural food colorant in a model system of a drink. Lebensmittel-Wissenschaft + Technologie, 41(8), 1437-1445. http://dx.doi.org/10.1016/j.lwt.2007.08.014.

Esatbeyoglu, T., Wagner, A. E., Schini-Kerth, V. B., \& Rimbach, G. (2015). Betanin - a food colorant with biological activity. Molecular Nutrition \& Food Research, 59(1), 36-47. http://dx.doi.org/10.1002/ mnfr.201400484. PMid:25178819.

Figiel, A. (2010). Drying kinetics and quality of beetroots dehydrated by combination of convective and vacuum-microwave methods. Journal of Food Engineering, 98(4), 461-470. http://dx.doi.org/10.1016/j. jfoodeng.2010.01.029.

Gonçalves, L. C. P., Di Genova, B. M., Dörr, F. A., Pinto, E., \& Bastos, E. L. (2013). Effect of dielectric microwave heating on the color and antiradical capacity of betanin. Journal of Food Engineering, 118(1), 49-55. http://dx.doi.org/10.1016/j.jfoodeng.2013.03.022.

Goula, A. M., Karapantsios, T. D., Achilias, D. S., \& Adamopoulos, K. G. (2008). Water sorption isotherms and glass transition temperature of spray dried tomato pulp. Journal of Food Engineering, 85(1), 73-83. http://dx.doi.org/10.1016/j.jfoodeng.2007.07.015.

Güneşer, O. (2016). Pigment and color stability of beetroot betalains in cow milk during thermal treatment. Food Chemistry, 196, 220-227. http://dx.doi.org/10.1016/j.foodchem.2015.09.033. PMid:26593486.

Halsey, G. (1985). Physical adsorption on uniform surfaces. The Journal of Chemical Physics, 16(10), 931-937. http://dx.doi.org/10.1063/1.1746689.

Henderson, S. M. (1952). A basic concept of equilibrium moisture. Agricultural Engineering, 33, 29-32.

Herbach, K. M., Stintzing, F. C., \& Carle, R. (2006). Betalain stability and degradation - structural and chromatic aspects. Journal of Food Science, 71(4), 41-50. http://dx.doi.org/10.1111/j.1750-3841.2006.00022.x.

Herrera-Hernández, M. G., Guevara-Lara, F., Reynoso-Camacho, R., \& Guzmán-Maldonado, S. H. (2011). Effects of maturity stage and storage on cactus berry (Myrtillocactus geometrizans) phenolics, vitamin C, betalains and their antioxidant properties. Food Chemistry, 129(4), 1744-1750. http://dx.doi.org/10.1016/j.foodchem.2011.06.042.

Jayaprakasha, G. K., Jaganmohan Rao, L., \& Sakariah, K. K. (2006). Antioxidant activities of curcumin, demethoxycurcumin and bisdemethoxycurcumin. Food Chemistry, 98(4), 720-724. http:// dx.doi.org/10.1016/j.foodchem.2005.06.037.

Jiménez-Aguilar, D. M., Ortega-Regules, A. E., Lozada-Ramírez, J. D., Pérez-Pérez, M. C. I., Vernon-Carter, E. J., \& Welti-Chanes, J. (2011). Color and chemical stability of spray-dried blueberry extract using mesquite gum as wall material. Journal of Food Composition and Analysis, 24(6), 889-894. http://dx.doi.org/10.1016/j.jfca.2011.04.012.

Khalil, O. A. K., Faria Oliveira, O. M. M., Vellosa, J. C. R., Quadros, A. U., Dalposso, L. M., Karam, T. K., Mainardes, R. M., \& Khalil, N. M. (2012). Curcumin antifungal and antioxidant activities are increased in the presence of ascorbic acid. Food Chemistry, 133(3), 1001-1005. http://dx.doi.org/10.1016/j.foodchem.2012.02.009.
Kruger, M. J., Davies, N., Myburgh, K. H., \& Lecour, S. (2014). Proanthocyanidins, anthocyanins and cardiovascular diseases. Food Research International, 59, 41-52. http://dx.doi.org/10.1016/j. foodres.2014.01.046.

Kus, E., \& Eroglu, H. E. (2015). Genotoxic and cytotoxic effects of sunset yellow and brilliant blue, colorant food additives, on human blood lymphocytes. Pakistan Journal of Pharmaceutical Sciences, 28(1), 227-230. PMID: 25553699.

Kutti Gounder, D., \& Lingamallu, J. (2012). Comparison of chemical composition and antioxidant potential of volatile oil from fresh, dried and cured turmeric (Curcuma longa) rhizomes. Industrial Crops and Products, 38(1), 124-131. http://dx.doi.org/10.1016/j. indcrop.2012.01.014.

Labuza, T. P., \& Schmidl, M. K. (1985). Accelerated shelf-life testing of foods. Food Technology, 39(9) 57-62.

Lim, H. S., Park, S. H., Ghafoor, K., Hwang, S. Y., \& Park, J. (2011). Quality and antioxidant properties of bread containing turmeric (Curcuma longa L.) cultivated in South Korea. Food Chemistry, 124(4), 1577-1582. http://dx.doi.org/10.1016/j.foodchem.2010.08.016.

Lin, C.-C., Lin, H.-Y., Chen, H.-C., Yu, M.-W., \& Lee, M.-H. (2009). Stability and characterisation of phospholipid-based curcuminencapsulated microemulsions. Food Chemistry, 116(4), 923-928. http://dx.doi.org/10.1016/j.foodchem.2009.03.052.

Martins, R. M., Pereira, S. V., Siqueira, S., Salomão, W. F., \& Freitas, L. A. P. (2013). Curcuminoid content and antioxidant activity in spray dried microparticles containing turmeric extract. Food Research International, 50(2), 657-663. http://dx.doi.org/10.1016/j. foodres.2011.06.030.

Mathlouthi, M., \& Rogé, B. (2003). Water vapour sorption isotherms and the caking of food powders. Food Chemistry, 82(1), 61-71. http://dx.doi.org/10.1016/S0308-8146(02)00534-4.

McCann, D., Barrett, A., Cooper, A., Crumpler, D., Dalen, L., Grimshaw, K., Kitchin, E., Lok, K., Porteous, L., Prince, E., Sonuga-Barke, E., Warner, J. O., \& Stevenson, J. (2007). Food additives and hyperactive behaviour in 3-year-old and 8/9-year-old children in the community: a randomised, double-blinded, placebo-controlled trial. Lancet, 370(9598), 1560-1567. http://dx.doi.org/10.1016/ S0140-6736(07)61306-3. PMid:17825405.

Mondal, S., Ghosh, S., \& Moulik, S. P. (2016). Stability of curcumin in different solvent and solution media: UV-visible and steadystate fluorescence spectral study. Journal of Photochemistry and Photobiology. B, Biology, 158, 212-218. http://dx.doi.org/10.1016/j. jphotobiol.2016.03.004. PMid:26985735.

Mosquera, L. H., Moraga, G., \& Martínez-Navarrete, N. (2012). Critical water activity and critical water content of freeze-dried strawberry powder as affected by maltodextrin and arabic gum. Food Research International, 47(2), 201-206. http://dx.doi.org/10.1016/j. foodres.2011.05.019.

Nemzer, B., Pietrzkowski, Z., Spórna, A., Stalica, P., Thresher, W., Michałowski, T., \& Wybraniec, S. (2011). Betalainic and nutritional profiles of pigment-enriched red beet root (Beta vulgaris L.) dried extracts. Food Chemistry, 127(1), 42-53. http://dx.doi.org/10.1016/j. foodchem.2010.12.081.

Oswin, C. R. (1946). The kinetics of package life III. The isotherm. Journal of Chemical Technology and Biotechnology (Oxford, Oxfordshire), 65(12), 419-421. http://dx.doi.org/10.1002/jctb.5000651216.

Pascual-Teresa, S. (2014). Molecular mechanisms involved in the cardiovascular and neuroprotective effects of anthocyanins. Archives of Biochemistry and Biophysics, 559, 68-74. http://dx.doi.org/10.1016/j. abb.2014.04.012. PMid:24791600. 
Pedro, A. C., Granato, D., \& Rosso, N. D. (2016). Extraction of anthocyanins and polyphenols from black rice (Oryza sativa L.) by modeling and assessing their reversibility and stability. Food Chemistry, 191, 12-20. http://dx.doi.org/10.1016/j.foodchem.2015.02.045. PMid:26258696.

Peng, G., Chen, X., Wu, W., \& Jiang, X. (2007). Modeling of water sorption isotherm for corn starch. Journal of Food Engineering, 80(2), 562-567. http://dx.doi.org/10.1016/j.jfoodeng.2006.04.063.

Pitalua, E., Jimenez, M., Vernon-Carter, E. J., \& Beristain, C. I. (2010). Antioxidative activity of microcapsules with beetroot juice using gum arabic as wall material. Food and Bioproducts Processing, 88(2-3), 253-258. http://dx.doi.org/10.1016/j.fbp.2010.01.002.

Piyarat, K., Walaisiri, M., \& Pornpen, W. (2014). Comparison of stability of red colorants from natural sources, roselle and lac in micelles. International Food Research Journal, 21(1), 325-330.

Re, R., Pellegrini, N., Proteggente, A., Pannala, A., Yang, M., \& RiceEvans, C. (1999). Antioxidant activity applying an improved ABTS radical. Free Radical Biology \& Medicine, 26(98), 1231-1237. http:// dx.doi.org/10.1016/S0891-5849(98)00315-3. PMid:10381194.

Reid, D. S., \& Fennema, O. R. (2010). Água e gelo. In S. Damodaran, K. L. Parkin \& O. R. Fennema. Química de alimentos de Fennema ( $4^{\text {a }}$ ed., pp. 25-74). Porto Alegre: Artmed.

Rodriguez-Amaya, D. B. (2016). Natural food pigments and colorants. Current Opinion in Food Science, 7, 20-26. http://dx.doi.org/10.1016/j. cofs.2015.08.004.

Rossi, J., \& Roa, G. (1980). Drying and storage of agricultural products with use of solar energy and natural air (Vol. 22, 296 p.). São Paulo: Academia de Ciências do Estado de São Paulo.

Rosso, V. V., \& Mercadante, A. Z. (2007). Evaluation of colour and stability of anthocyanins from tropical fruits in an isotonic soft drink system. Innovative Food Science \& Emerging Technologies, 8(3), 347-352. http://dx.doi.org/10.1016/j.ifset.2007.03.008.

Silva, P. I., Stringueta, P. C., Teófilo, R. F., \& Oliveira, I. R. N. (2013). Parameter optimization for spray-drying microencapsulation of jaboticaba (Myrciaria jaboticaba) peel extracts using simultaneous analysis of responses. Journal of Food Engineering, 117(4), 538-544. http://dx.doi.org/10.1016/j.jfoodeng.2012.08.039.

Singh, G., Kapoor, I. P. S., Singh, P., Heluani, C. S., Lampasona, M. P., \& Catalan, C. A. N. (2010). Comparative study of chemical composition and antioxidant activity of fresh and dry rhizomes of turmeric (Curcuma longa Linn.). Food and Chemical Toxicology, 48(4), 10261031. http://dx.doi.org/10.1016/j.fct.2010.01.015. PMid:20096323.

Souza, V. B., Fujita, A., Thomazini, M., Silva, E. R., Lucon, J. F. Jr., Genovese, M. I., \& Favaro-Trindade, C. S. (2014). Functional properties and stability of spray-dried pigments from Bordo grape (Vitis labrusca) winemaking pomace. Food Chemistry, 164, 380-386. http://dx.doi.org/10.1016/j.foodchem.2014.05.049. PMid:24996348.

Souza, V. B., Thomazini, M., Balieiro, J. C. D. C., \& Fávaro-Trindade, C. S. (2015). Effect of spray drying on the physicochemical properties and color stability of the powdered pigment obtained from vinification byproducts of the Bordo grape (Vitis labrusca). Food and Bioproducts Processing, 93, 39-50. http://dx.doi.org/10.1016/j.fbp.2013.11.001.
Statsoft Inc. (2004). Statistica: data analysis software system. Version 7.0. Tulsa: Statsoft Inc.

Stevens, L. J., Kuczek, T., Burgess, J. R., Hurt, E., \& Arnold, L. E. (2011). Dietary sensitivities and ADHD symptoms: thirty-five years of research. Clinical Pediatrics, 50(4), 279-293. http://dx.doi. org/10.1177/0009922810384728. PMid:21127082.

Sui, X., Dong, X., \& Zhou, W. (2014). Combined effect of pH and high temperature on the stability and antioxidant capacity of two anthocyanins in aqueous solution. Food Chemistry, 163, 163-170. http://dx.doi.org/10.1016/j.foodchem.2014.04.075. PMid:24912712.

Suresh, D., Manjunatha, H., \& Srinivasan, K. (2007). Effect of heat processing of spices on the concentrations of their bioactive principles: turmeric (Curcuma longa), red pepper (Capsicum annuum) and black pepper (Piper nigrum). Journal of Food Composition and Analysis, 20(3-4), 346-351. http://dx.doi.org/10.1016/j.jfca.2006.10.002.

Syamaladevi, R. M., Sablani, S. S., Tang, J., Powers, J., \& Swanson, B. G. (2009). State diagram and water adsorption isotherm of raspberry (Rubus idaeus). Journal of Food Engineering, 91(3), 460-467. http:// dx.doi.org/10.1016/j.jfoodeng.2008.09.025.

Szulc, K., \& Lenart, A. (2012). Water vapour adsorption properties of agglomerated baby food powders. Journal of Food Engineering, 109(1), 135-141. http://dx.doi.org/10.1016/j.jfoodeng.2011.09.023.

Taylor, A. A. (1961). Determination of moisture equilibrium in dehydrated foods. Food Technology, 15, 536-540.

Tonon, R. V., Baroni, A. F., Brabet, C., Gibert, O., Pallet, D., \& Hubinger, M. D. (2009). Water sorption and glass transition temperature of spray dried açai (Euterpe oleracea Mart.) juice. Journal of Food Engineering, 94(3-4), 215-221. http://dx.doi.org/10.1016/j.jfoodeng.2009.03.009.

Tonon, R. V., Brabet, C., \& Hubinger, M. D. (2010). Anthocyanin stability and antioxidant activity of spray-dried açai (Euterpe oleracea Mart.) juice produced with different carrier agents. Food Research International, 43(3), 907-914. http://dx.doi.org/10.1016/j. foodres.2009.12.013.

Vulić, J., Čanadanović-Brunet, J., Ćetković, G., Tumbas, V., Djilas, S., Četojević-Simin, D., \& Čanadanović, V. (2012). Antioxidant and cell growth activities of beet root pomace extracts. Journal of Functional Foods, 4(3), 670-678. http://dx.doi.org/10.1016/j.jff.2012.04.008.

Wootton-Beard, P. C., \& Ryan, L. (2011). A beetroot juice shot is a significant and convenient source of bioaccessible antioxidants. Journal of Functional Foods, 3(4), 329-334. http://dx.doi.org/10.1016/j. jff.2011.05.007.

Xu, J., Su, X., Lim, S., Griffin, J., Carey, E., Katz, B., Tomich, J., Smith, J. S., \& Wang, W. (2015). Characterisation and stability of anthocyanins in purple-fleshed sweet potato P40. Food Chemistry, 186, 90-96. http://dx.doi.org/10.1016/j.foodchem.2014.08.123. PMid:25976796.

Yang, Z., \& Zhai, W. (2010). Identification and antioxidant activity of anthocyanins extracted from the seed and cob of purple corn (Zea mays L.). Innovative Food Science \& Emerging Technologies, 11(1), 169-176. http://dx.doi.org/10.1016/j.ifset.2009.08.012. 